\title{
English Learner Policies into Practice: The Power of Campus Leadership
}

\author{
Vanessa de León, Katie Walker, Andrea Moreno Juarez \\ College of Education, Texas Tech University, Educational Leadership, Lubbock, USA \\ Email: vanessa.deleon@ttu.edu
}

How to cite this paper: de León, V., Walker, K., \& Juarez, A. M. (2021). English Learner Policies into Practice: The Power of Campus Leadership. Open Journal of Leadership, $10,161-168$.

https://doi.org/10.4236/oj1.2021.102011

Received: May 20, 2021

Accepted: June 27, 2021

Published: June 30, 202

Copyright (c) 2021 by author(s) and Scientific Research Publishing Inc. This work is licensed under the Creative Commons Attribution International License (CC BY 4.0).

http://creativecommons.org/licenses/by/4.0/ (c) (i) Open Access

\begin{abstract}
English learners (ELs) are a central and yet marginalized student population attending many public schools today. There are currently language policies written into legislation that provides support for EL students. The question is, how do the beliefs of school leaders influence their response to issues of policy implementation and compliance for EL students? In this study, campus administrators (leaders) in Texas school districts utilize responsive interviews to examine how the beliefs and practices of campus administrators shape their response to issues of compliance and implementation of language policies for ELs indicating how leaders accept educational responsibility for EL students. Ultimately, successful campuses are bred through a supportive, culturally competent climate and culture that is modeled and nurtured through an involved campus administrator who is willing to accept educational responsibility for EL students.
\end{abstract}

\section{Keywords}

Leadership, Bilingual Program, ESL Program, Policy for EL Students, EL Policy to Practice

\section{Introduction}

English learners continue to be an underserved population with diverse needs and English learner policies are lost in translation within the practice. In the United States, 25\% of children are children of immigrants and 10.5\% are English Learners referred to as ELs (Batalova \& McHugh, 2010). This statistic increased by $53.2 \%$ from 1997-2008. In Texas, 19\% of students are identified as English Learners, and over 130 languages are represented in schools (TEA, 2018). Today's educators are faced with finding new solutions to support the linguistically and culturally diverse ELs in their schools (Heineke, 2014; Stewart, 2012). 
Despite the work of many well-intentioned educators, ELs still exist as a marginalized population in schools (Cummins, 2001; Olsen, 2009). The language used in policies related to ELs highlights the lack of understanding among policy-makers about how to best serve ELs. The language points to a child who is defined by their language alone, with little consideration given to culture or educational background. These students arrive at our schools with diverse languages and language experiences, cultures and cultural experiences, education, and educational experiences. The complex needs of EL students often overwhelm educators and educational leaders who lack the support needed to meet the needs of this population (Boyd, 2013).

Historically, little progress is made in campus ESL programs unless complete buy-in from the campus administration is present. Darling-Hammond (2010) discussed how successful districts and schools created reform. Though not directly stated, all reforms identified require leadership that is involved, innovative, consistent, and supportive. To build successful ESL programs, it is crucial to have the full support and involvement of campus administrators (Brooks, JeanMarie, Normore, \& Hodgins, 2007). This study attempts to answer the question, how do the beliefs and practices of campus administrators shape their response to issues of compliance and implementation of language policies for ELs? The idea of accepting educational responsibility for EL students is one that is a focus for many campus administrators.

In this study, campus leaders in Texas school districts utilized responsive interviews to examine how the beliefs and practices of campus administrators shape their response to issues of compliance and implementation of language policies for ELs.

\section{Perspectives from Language Policies in the United States}

The history of immigrant education in the United States has been shaped primarily through the civil rights legislation in the 1970s and 1980s (Diem \& Frankenburg, 2013; Olsen, 2009). According to Olsen (2009), the goals of this movement focused on assimilation and Americanizing immigrants, providing equitable opportunities, and providing instruction that targeted English proficiency with little place for home languages or cultures.

The majority of policies developed regarding second-language literacy in Texas and the United States have focused on the responsibility of schools to provide support and educational access for students who are not fluent in English. State bills do differentiate between bilingual education and instruction for ESL with different goals for each. Texas state bills regarding bilingual education focus on providing initial literacy instruction in the native language as an avenue to developing proficiency in English, while bills regarding ESL focus on the use of linguistic supports to develop conceptual knowledge while students are simultaneously developing proficiency in English (TABE, 2006).

Though these policies were developed by well-intentioned parties, the majori- 
ty of these policies were framed by policy-makers who see non-fluent English speakers as being at a deficit. As Cummins (2001) explained:

When we choose to frame the discourse about underachievement primarily in terms of children's deficits in some area of psychological or linguistic functioning, we expel culture, language, identity, intellect, and imagination from our image of the child, and we eliminate these constructs from our image of the effective teacher of these children, and from policies that might guide instruction. (p. 654).

In other words, when policies are developed through a deficit frame, we forget that the priority of education is to educate all children. If the goal is truly to provide equitable educational access, then educational leaders and policy-makers must begin to frame the dialogue related to second-language acquisition through a frame that values the funds of knowledge of all languages, cultures, communities, families, students, and educators.

Garcia and Wei (2014) acknowledged the changing language practices that are required to become part of today's workforce. "Today ... language practices neither correspond to official national borders nor respond to a single center of power or express a unitary identity," (Garcia \& Wei, 2014: p. 59). Language practices no longer represent pure usages of any particular language, but mesh together social, cultural, and linguistic practices from a variety of sources to create new and unique linguistic structures that reflect the lived language of people in the 21st Century. Unfortunately, Garcia (2014) and Burns (2012) suggested that while educational systems may be adjusting to address other 21st Century skills, educational policy and the educational community have offered little recognition of changes in language.

\section{Significance of the Campus Leader}

When the question is posed to campus administrators, "In what way do you support your campus ESL program?", the response is either that the ESL teacher manages the campus ESL program and does a great job or that they are present for the Language Proficiency Assessment Committee (LPAC) meetings, as required by law. Theoharis and O'Toole (2011) found that principals who were successful in supporting ELs held a personal feeling of responsibility and agency for the ELs on campus.

The importance of campus administrators building relationships with ELs and their families is a major theme highlighted in current research (Gerhart, Harris, \& Mixon, 2011; Madhlangobe \& Gordon, 2012; Riehl, 2000; Theoharis \& O'Toole, 2011). "For a school to be multicultural, each child must feel welcome, safe, and included in the school community," (Gerhart, Harris, \& Mixon, 2011: p. 269). Theoharis and O'Toole (2011) stated that campus administrators who maintain an asset-based view of students and families are more successful in building supportive relationships. Many ELs are either the children of immigrants or immigrants themselves, making it essential for administrators to take the time to 
understand the stories of families and students that they are serving. Campus administrators create systems to reach students and families, thus meeting the social, emotional, and academic needs of EL students. Oftentimes, campus administrators rely on their staff to meet the needs of students. When administrators defer students and families to the ESL teacher, this piece is often missed and the gap in understanding between campus administrators and their EL population widens (Brooks, Adams, \& Morita-Mullaney, 2010).

Madhlangobe and Gordon (2012) provide an example of a campus administrator who addresses these needs by eliminating traditional power structures and putting herself on a level playing field with parents, students, and teachers. She viewed the dependence of the success of her ESL program to be based on collaborative and communicative relationships. Madhlangobe and Gordon (2012) demonstrated that this administrator was open to parent perspectives and utilized student testimonies in breakfast clubs with teachers to help them build cultural awareness.

According to Gerhart, Harris and Mixon (2011), consistently high expectations, both academic and disciplinary, are essential for maintaining supportive relationships and a culturally responsive campus. Unfortunately, outside of the ESL teacher's classroom, ELs often experience less qualified teachers than nonELs (Samson \& Lesaux, 2015). These teachers often lack qualifications and access to the appropriate support to increase their effectiveness in teaching ELs. The result is that the EL is ignored in the class or is sent to complete their work with the ESL teacher, similar to how a student who is serviced through special education might be sent to content mastery, where the students take their classwork to a teacher who may not be specialized in the specific subject area and/ or is not specialized in tools needed to assist with the learning of EL students. This situation increases stress for both the student and the teacher. "Anxiety causes people, especially young minority students, to avoid participating in school interactions because they fear making mistakes in front of other people, which could cause others to criticize or humiliate them." (Madhlangobe, \& Gordon, 2012: p. 187).

When campus administrators appoint the ESL teacher as the role of expert, this behavior becomes institutionalized as the remaining teachers fail to see their role in supporting ELs. The sense of ownership and shared responsibility becomes siloed as general education teachers see no need to interact with EL students due to the presence of the ESL teachers. Administrators who were successful in supporting their EL programs maintained supportive relationships with their EL students, ESL teachers, and general education teachers by offering shared ownership and assuming responsibility to work together to meet the needs of the students. To maintain culturally responsive campuses, high expectations must be held for all students regardless of language, culture, socio-economic status, or educational background (Gerhart, Harris, \& Mixon, 2011). 


\section{Methodology}

This qualitative study utilizes planned responsive interviews (Rubin \& Rubin, 2012) to obtain data between 2015 to 2016. This study attempts to answer the question, how do the beliefs and practices of campus administrators shape their response to issues of compliance and implementation of language policies for ELs?

To conduct the necessary research, a proposal was sent to the Institutional Review Board (IRB) for approval as a means of ensuring that the appropriate steps are taken to protect the rights and well-being of the research subjects. After approval was granted, the participants were contacted, informed of the approval, and the contact information of the IRB was provided to them in case questions or concerns arose.

This inquiry focuses on the experiences of individual campus administrators in Texas school districts' incorporation of implementing educational policy into practice when serving EL students. Once the researcher received a positive response of interest from the recruitment email, the researcher contacted the administrator to schedule a meeting at the place and time most convenient for the administrator. This meeting lasted approximately 30 - 45 minutes in length depending on the length of the responses of the administrator to the interview questions. The interview questions used are listed in Table 1. Initial data is collected, categorized, and reported in a qualitative format.

Table 1. Interview protocol.

Interview Protocol

1) What are your beliefs about effective programming and instruction for ELs?

a) What do you believe are the most common challenges that ELs face?

How do you prepare to respond to these challenges?

b) What do you believe are the most common strengths of ELs?

How do you prepare to capitalize on these strengths?

2) In what ways do you think your beliefs related to ELs shape your response to issues of compliance and implementation of language policies?

a) How do you make decisions about how your campus ESL program will be implemented?

b) In what way do language policies influence your interaction with the ELs on your campus?

c) What are the most common struggles that you or your campus face when responding to issues of compliance and implementation of language policies?

d) What support is available to you during implementation?

e) Please describe what the typical day of an EL on your campus might look like.

f) What structures are in place to support the academic success of ELs on your campus?

g) What role do you play in supporting ELs?

h) How do you decide who on your campus will be responsible for serving ELs?

What is most important to you when making staffing decisions related to ESL?

3) Do you believe that the current policy adequately supports the needs of ELs on your campus or do you feel that the policies could be improved upon? Please describe.

a) In what ways do you think campus administrators might interpret language policies in ways that support or don't support the academic success of ELs? 


\section{Results and Findings}

\subsection{Figures and Tables}

The final analysis of data includes a compilation of codes identifying trends and patterns. The qualitative data analyses include ways of intentionally organizing data in a way that allows the researcher to see patterns and relationships among the details. To analyze the data, particular data concepts were monitored based on the coding. Broad themes and generalizations are actions that occur during this step of the research. The final analysis step and style of documentation allow the confirmation of trends, data synthesis, and the identification of findings and recommendations.

\subsection{Finding 1}

On campuses where administrators have fostered collaborative and supportive relationships, these relationships extend throughout the school web (Madhlangobe \& Gordon, 2012) bringing the ESL teacher into a collaborative partnership that naturally produces more tools and resources. Furthermore, these relationships extend from the teachers to the students, to the parents, and to the community (Brooks, Jean-Marie, Normore, \& Hodgins, 2007; Madhlangobe \& Gordon, 2012; Muller, 2001). The data shows that sustainability is stronger when stakeholders are involved in planning and decision-making when implementing EL policy as practice. The data also shows that when stakeholders are not involved in EL planning and decision making, the policy to practice becomes fragmented leading to descending academic results.

\subsection{Finding 2}

This community approach to ESL programming empowers all stakeholders and often leads to advocacy among teachers. Freire (1998) said that it was a teacher's moral obligation to advocate for their students. This advocacy could happen in a variety of ways, as the history of ESL instruction is so fraught with political ideals. Language education policy both reflects and influences wider ideologies and attitudes about critical issues such as language, culture, immigration, diversity, and national identity. As such, research in this area serves as a powerful lens through which to analyze and expose issues of power and marginalization in educational contexts (Menken \& Solorza, 2014: p. 100).

\subsection{Finding 3}

The data reveals that advocacy and action for EL students improve student achievement. One of the most practical ways for campus administrators to advocate for their students is to guarantee that EL students have access to highquality teachers. The data shows that human capital and human capacity are one of the greatest resources. Leaders who intentionally build the EL capacity of teachers demonstrate improvement in student achievement. 


\section{Conclusion}

The campus administrator cultivates relationships through communication, involvement, and a forward or proactive approach to the implementation of EL policy. Campus administrators must build the EL knowledge of teachers, students, parents, and leaders using effective EL strategies and a growth mindset. Successful campuses are bred through a supportive, culturally competent climate and culture that has been modeled and nurtured through an involved administrator who is willing to accept educational responsibility for EL students. Rather than waiting for problems to arise, the proactive leader seeks input from stakeholders and establishes relationships as well as accessible communication systems, allowing for the EL policy implementation to become best practice.

\section{Conflicts of Interest}

The authors declare no conflicts of interest regarding the publication of this paper.

\section{References}

Batalova, J., \& McHugh, M. (2010). Number and Growth of Students in US Schools in Need of English Instruction. Washington DC: Migration Policy Institute.

Boyd, F. B. (2013). Wading through the Consequences of Policy Decisions. Journal of Adolescent \& Adult Literacy, 57, 12-15. https://doi.org/10.1002/JAAL.207

Brooks, J. S., Jean-Marie, G., Normore, A. H., \& Hodgins, D. W. (2007). Distributed Leadership for Social Justice: Exploring How Influence and Equity Are Stretched over an Urban High School. Journal of School Leadership, 17, 378-408. https://doi.org/10.1177\%2F105268460701700402

Brooks, K., Adams, S. R., \& Morita-Mullaney, T. (2010). Creating Inclusive Learning Communities for ELL Students: Transforming School Principals' Perspectives. Theory into Practice, 49, 145-151. https://doi.org/10.1080/00405841003641501

Burns, L. D. (2012). Standards, Policy Paradoxes, and the New Literacy Studies: A Call to Professional Political Action. Journal of Adolescent \& Adult Literacy, 56, 93-97. https://doi.org/10.1002/JAAL.00108

Cummins, J. (2001). Empowering Minority Students: A Framework for Intervention. Harvard Educational Review, 71, 649-675. https://doi.org/10.17763/haer.71.4.j261357m62846812

Darling-Hammond, L. (2010). The Flat World and Education: How America's Commitment to Equity Will Determine Our Future. New York, NY: Teachers College Press.

Diem, S., \& Frankenburg, E. (2013). The Politics of Diversity: Integration in an Era of Political and Legal Uncertainty. Teachers College Record, 115, 1-30.

Freire, P. (1998). Pedagogy of Freedom: Ethics, Democracy, and Civic Courage. Lanham, MD: Rowman \& Littlefield Publishers, Inc.

Garcia, O. (2014). U.S. Spanish and Education: Global and Local Intersections. In K. M. Borman, T. G. Wiley, D. R. Garcia, \& A. B. Danzig (Eds.), Review of Research in Education: Language Policy, Politics, and Diversity in Education (pp. 58-80). Thousand Oaks, CA: Sage Publications.

Garcia, O., \& Wei, L. (2014). Translanguaging: Language, Bilingualism, and Education. New York, NY: Palgrave MacMillan. https://doi.org/10.1057/9781137385765 
Gerhart, L. G., Harris, S., \& Mixon, J. (2011). Beliefs and Effective Practices of Successful Principals in High Schools with a Hispanic Population of at Least 30\%. NASSP Bulletin, 95, 266-280. https://doi.org/10.1177\%2F0192636511428373

Heineke, A. J. (2014). Dialoging about English Learners: Preparing Teachers through Culturally Relevant Literature Circles. Action in Teacher Education, 36, 117-140. https://doi.org/10.1080/01626620.2014.898600

Madhlangobe, L., \& Gordon, S. P. (2012). Culturally Responsive Leadership in a Diverse School: A Case Study of a High School Leader. NASSP Bulletin, 96, 177-202. https://doi.org/10.1177\%2F0192636512450909

Menken, K., \& Solorza, C. (2014). No Child Left Bilingual: Accountability and the Elimination of Bilingual Education Programs in New York City Schools. Educational Policy, 28, 96-125. https://doi.org/10.1177\%2F0895904812468228

Muller, C. (2001). The Role of Caring the Teacher-Student Relationship for At-Risk Students. Sociological Inquiry, 71, 241-255. https://doi.org/10.1111/j.1475-682X.2001.tb01110.x

Olsen, L. (2009). The Role of Advocacy in Shaping Immigrant Education: A California Case Study. Teachers College Record, 111, 817-850.

Riehl, C. J. (2000). The Principal's Role in Creating Inclusive Schools for Diverse Students: A Review of Normative, Empirical, and Critical Literature in the Practice of Educational Administration. Review of Educational Research, 70, 55-81. https://doi.org/10.3102\%2F00346543070001055

Rubin, H. J., \& Rubin, I. S. (2012). Qualitative Interviewing: The Art of Hearing Data. Thousand Oaks, CA: SAGE Publications.

Samson, J. F., \& Lesaux, N. (2015). Disadvantaged Language Minority Students and Their Teachers: A National Picture. Teachers College Record, 117, Article ID: 020301.

Stewart, M. A. (2012). Juxtaposing Immigrant Girl and Adolescent Girl Experiences: Literature for All Readers. English Journal, 101, 17-22.

Texas Association for Bilingual Education (TABE) (2006). A Plan for Providing Effective Linguistic and Academic Instruction for English Language Learners in Texas: An Action Plan for a Quality Education for ELLs Submitted by the Texas Association for Bilingual Education (TABE).

https://senate.texas.gov/cmtes/80/c530/0623-Leo-Gomez-1.pdf

Texas Education Agency (TEA) (2018). Building Capacity to Staff Bilingual Programs. Austin, TX: Texas Education Agency. https://bit.ly/35KZvlK

Theoharis, G. \& O’Toole, J. (2011). Leading inclusive ELL: Social Justice Leadership for English Language Learners. Educational Administration Quarterly, 47, 646-688. https://doi.org/10.1177\%2F0013161X11401616 